\title{
Anthropic effects on the fish community of Ribeirão Claro, Rio Claro, SP, Brazil
}

\author{
Ferreira, FC. and Petrere Jr., M.* \\ Departamento de Ecologia, Instituto de Biociências, UNESP, CP 199, CEP 13506-900, Rio Claro, SP, Brazil \\ *e-mail: mpetrere@rc.unesp.br \\ Received November 23, 2004 - Accepted March 9, 2005 - Distributed February 28, 2007
}

(With 1 figure)

\begin{abstract}
The effect of anthropic alterations such as drain discharge on a fish community was studied in the Ribeirão Claro River, municipality of Rio Claro, State of São Paulo, southeastern Brazil. Samples were made monthly in three different points along the river (headwaters, mid course, and confluence) between December, 2003 and March, 2004, which is the reproductive period for the majority of the species. The fish community of the Ribeirão Claro River showed a fair composition and diversity, with species rarely observed in studies made in the region, such as Paravandellia oxyfera and Callichthys callichthys. Indices of diversity and equitability showed different results when weight or the number of individuals were considered. Moreover, these indices did not reveal the typical increase in diversity from the headwaters toward the confluence, nor the loss of richness in the part altered by drain discharge. An interpretation should be made with caution, taking into account the diverse factors included in the computation. Similar to the diversity indices, the Morisita-Horn similarity index did not reveal a great difference in the fish community of the confluence of the river, mainly in relation to its mid course. The decline of species richness and trophic composition alteration in the disturbed part is clear, which shows a great dominance of piscivorous species.
\end{abstract}

Keywords: diversity indices, freshwater fish community, pollution effects, Ribeirão Claro, Brazil.

\section{Efeitos antrópicos na comunidade de peixes do Ribeirão Claro, Rio Claro, SP}

\begin{abstract}
Resumo
Com o objetivo de verificar o efeito de alterações antrópicas, como o despejo de esgotos sobre a comunidade de peixes do Ribeirão Claro, SP, foram feitas coletas mensais em três pontos ao longo do rio (cabeceira, meio e foz) entre dezembro de 2003 e março de 2004, período reprodutivo para a maioria das espécies da região. O Ribeirão Claro apresentou boa composição e variedade em sua comunidade íctia, possuindo espécies raramente observadas em trabalhos na região, como Paravandellia oxyfera e Callichthys callichthys. Os índices de diversidade e equitabilidade apresentaram diferentes resultados quando considerado o peso ou número de indivíduos, além de não evidenciarem o comportamento típico de aumento da diversidade no sentido cabeceira-foz, nem a conseqüente perda de riqueza taxonômica no trecho impactado pelo despejo de esgoto doméstico. Sua interpretação deve ser feita com cautela, considerando os diversos aspectos incluídos em seus cálculos. Assim como os índices de diversidade, a similaridade de Morisita-Horn não ressaltou a grande diferença na comunidade da foz do Ribeirão Claro, em especial com relação ao trecho médio do rio. Fica evidente o declínio na riqueza de espécies no trecho poluído e a alteração em sua composição trófica, apresentando alta dominância de espécies piscívoras.
\end{abstract}

Palavras-chave: Índices de diversidade, comunidade de peixes de água doce, efeitos da poluição, Ribeirão Claro, Brasil.

\section{Introduction}

The ecological community may be defined as an assemblage of species that occur together in space and/or time. The definition of community limits can be restricted to traits that may focus on taxonomic levels, scales or type of activity (e.g., feeding habits, habitat occupation, etc.) (Begon et al., 1996; Stiling, 1996; Chapman and Reiss, 1997).

Species use resources in different ways. The degree of interaction among species and between species and the environment has been explained by different theoretical currents since the beginning of the past century. In one extreme, communities are believed to be structured as "ecological entities", non-randomly organized and mostly dependent on biotic relationships (competition, 
predation, mutualism, etc.). At the other extreme, communities are defined as being randomly formed simply by the intrinsic traits of each species which enable them to withstand habitat physical alterations (Ricklefs, 1993; Peres-Neto, 1995; Súarez and Petrere, 2003).

Along the watershed, the gradual alteration in characteristics of rivers and streams involves physico-chemical and hydrological changes having deep effects on the energy flow between the biotic and abiotic components of the system (Vannote et al., 1980) due to variations in water current, temperature, dissolved oxygen, substratum, and water volume in the channel (Petts and Calow, 1996; Welcomme, 1994; Barrella et al., 2000). Thus, differences in community composition at different parts of the river are expected.

Considering the different habitats present, the success of a species will depend on the occurrence of suitable conditions which enable them to complete their life cycle. The initial growth stages, avoidance of predators, diseases and reproductive processes when new individuals are produced and incorporated into the community are crucial phases (Lowe-McConnell, 1999).

The Piracicaba River basin is located close to large urban centers, including municipalities where the mean populational increase in the last decades has been higher than that observed for the whole State of São Paulo. Moreover, a great migration movement from rural areas towards the cities has being occurring, increasing the urbanization rate by $92 \%$ (Garcia et al., 2004). Negri (1992) apud Palma-Silva (1999) pointed out that the populational increase in the region increased water use and drain discharge by $50 \%$. Since 2000, all the water consumed in the municipality of Piracicaba comes from the Corumbataí River.

Problems related to the loss of quality and scarcity of water in urban zones has increased over the last decade, as well as the impoverishment of the biological diversity in water bodies (Palma-Silva, 1999; Garcia et al., 2004). Drain discharge and deforestation are among the main causes of this situation.

Law \#2492 from 6 August, 1992 (Prefeitura de Rio Claro, 1992) states in article Art. $101^{\circ}$ that "an emergency plan of desiltation and recovering of the Ribeirão Claro and Corumbataí river basins aims to ensure the quality of water to the municipality" and $\left(84^{\circ}, \mathrm{XI}, \mathrm{b}\right)$ "that the Ribeirão Claro river basin shall be the most important source of drinking water for the city".

Despite this situation, the sub-basin of the Corumbataí River is one of the last basins in the state still presenting good quality water and is an alternative of water supply to many municipalities in the vicinity, besides presenting ecosystems with rare landscape elements in the interior of São Paulo. Its preservation and adequate management are of fundamental importance for the region and for the whole State.

The aim of this study is to analyze the longitudinal distribution of diversity of the fish community in the Ribeirão Claro (tributary of the Corumbataí River) and to analyze the influence of the drain "in natura" discharged in the confluence in such diversity.

\section{Materials and Methods}

\subsection{Study site}

The study site is included in the Corumbataí River basin, with an area of $1,700 \mathrm{~km}^{2}$ and a population of approximately 550,000 inhabitants in six municipalities, including Rio Claro. This drainage is part of the first Hydrographic Zone of the State of São Paulo from the headwaters of the Tietê River up to the storage dam of Barra Bonita, comprising 10 basins. The Piracicaba basin is among them, which is formed by the sub-basins of the Jaguari, Corumbataí and Atibaia rivers (CETESB, 1984).

Among the rivers that form the Corumbataí River basin, the Ribeirão Claro and its tributaries (22 $36^{\circ}$ $20^{\circ} 16^{\prime} \mathrm{S}$ and $46^{\circ} 36^{\prime} \mathrm{W}-47^{\circ} 26^{\prime} \mathrm{W}$ ) drain an area of $291 \mathrm{~km}^{2}$ (Spicacci, 1990). Its spring is located in the municipality of Corumbataí and crosses the east portion of the urban zone of the municipality of Rio Claro, including the protected area of the Floresta Estadual "Edmundo Navarro de Andrade". The municipal water reservoir is situated in this protected site. The area upstream from the reservoir represents $66.7 \%$ of the total sub-basin drainage area (Spicacci,1990).

The discharge of drains from the municipalities of Rio Claro and Santa Gertrudes begins a few meters downstream from the reservoir. From this point, the waters present a great amount of organic pollutants (Spicacci, 1990; Pedro Neto, 1996; Gertel, 2002; Cetra, 2003), which is the main cause of alterations in the part of the confluence of the Corumbataí River (Palma-Silva, 1999). Environmental alterations in the lower part of the Ribeirão Claro and the two dams, one in the municipal water reservoir and the other close to the confluence, determine an isolated fish community with distinct characteristics compared to other rivers in the basin (Cetra, 2003).

\subsection{Experimental design}

Fish were collected monthly, from December 2003 to March 2004, in three parts of the Ribeirão Claro River (Figure 1): the headwater region, the mid-portion and the confluence. The first point is approximately $15 \mathrm{~km}$ distant from the springs and the vegetation mainly consists of pastures. The second point is situated in the protected area of the Floresta Estadual "Edmundo Navarro de Andrade" with preserved marginal vegetation and an extensive gallery forest. The third point in the confluence has completely altered marginal vegetation consisting of pasture, lianas and eucalyptus, and with an area less than $20 \%$ shaded. Concerning the water quality, the urban drains are the most important difference between this part and the others. 


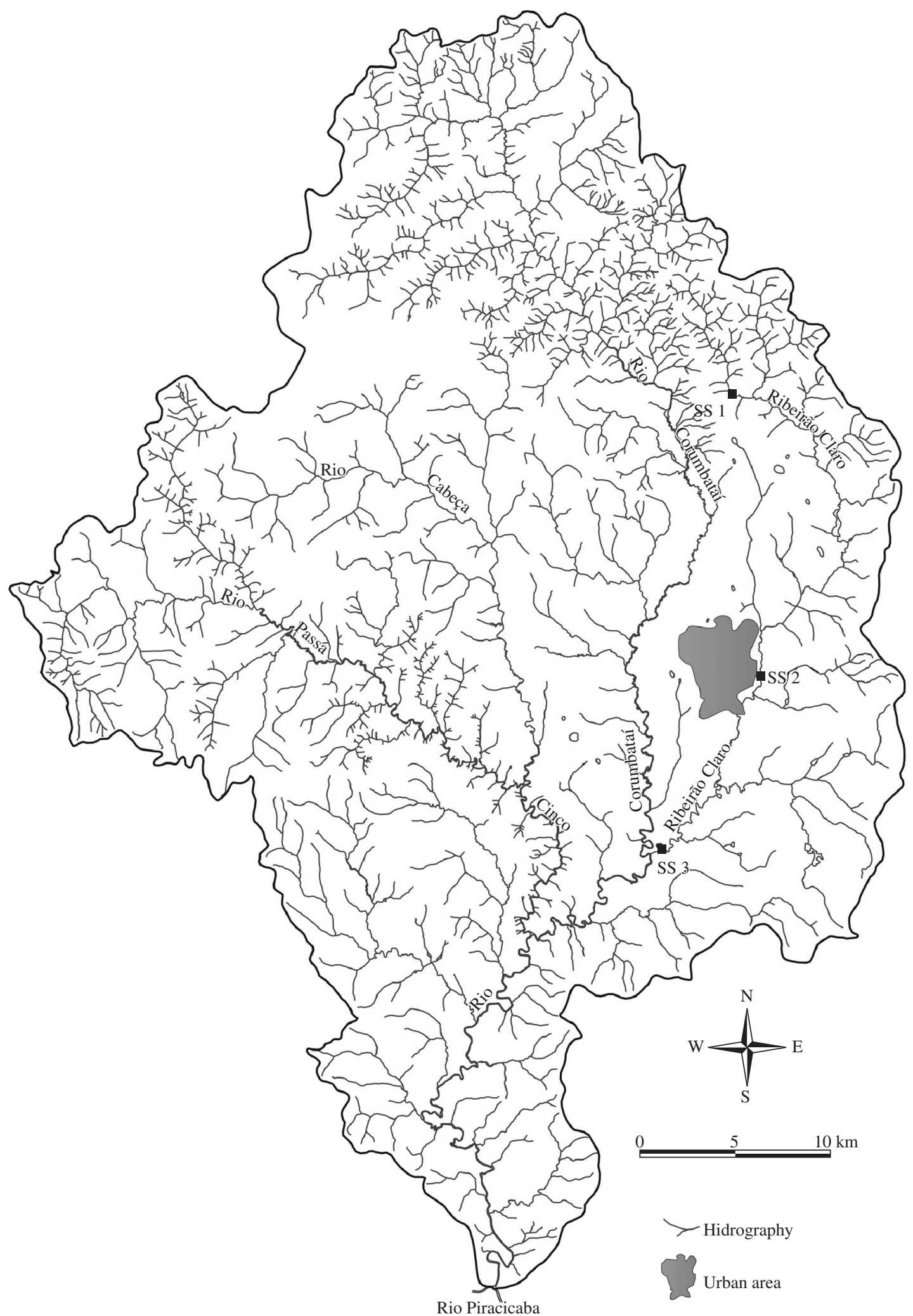

Figure 1. Hydrographic map of the Corumbataí River Basin, showing the sampled sites (modified from Garcia et al., 2004). SS1- Sample site 1; SS2 - Sample site 2; and SS3 - Sample site 3. 


\subsection{Sample and ichthyofauna analysis}

We used six gill nets with mesh sizes from 3 to $8 \mathrm{~cm}$ (opposed Knots) and two pairs of funnel traps set along approximately $100 \mathrm{~m}$ in the channel. A sample effort was standardized between the end of the afternoon and the next morning. Fish were separated by points and dates of sample and fixed in formalin $10 \%$. In the laboratory, individuals were measured (standard length and weight) and identified according to Britski et al. (1999) and Britski et al. (1984). Dr. Leandro Muller Gomiero from the Departamento de Zoologia da UNESP-Rio Claro helped us identify the fish.

From each sample, we calculated the diversity (base 2 logarithm) and equitability of Shannon-Wiener for the number and weight of individuals separately using the Jackknife method (Magurran, 1988) to obtain the estimates of the confidence intervals. To observe differences in the community composition along the river, parametric one-factor ANOVAs and non parametric KruskalWallis and posteriori tests of Scheffé and non parametric Q statistics (Zar, 1999) were carried out with the data on species diversity and equitability. To verify similarity patterns in species composition among the points, we calculated the Morisita-Horn index (Krebs, 1999).

\section{Results}

\subsection{Fish community general characteristics}

A total of 646 fish included in 31 species were collected over the four months of sampling with a weight of $9.4 \mathrm{~kg}$. Of the total weight, point 2 contributed to approximately $53 \%$ and point 3 to only about $7 \%$. No fish were caught in point 3 in December.

The majority of the individuals belong to the order Characiformes, with 19 species $(61.3 \%)$, followed by the order Siluriformes, with nine species (29\%), Gymnotiformes, with two species (6.5\%), and Perciformes, with one species $(3.2 \%)$. The family Characidae was represented by 12 species $(38.7 \%)$ and the number of species in the remaining families varied between one to three (Table 1).

The major contribution was given by Serrapinus heterodum with 300 individuals $(46.4 \%)$. These specimens were captured at site 1, mainly in February and March (156 and 132 individuals, respectively). Following, more abundant species were Astyanax altiparanae, Steindachnerina insculpta, Hypostomus ancistroides, Hoplias malabaricus, Cyphocharax modestus and Serrasalmus spilopleura, accounting for about $83 \%$ of the capture in number. Four species were represented by only one individual: Parodon tortuosos, Leporinus sp.1, Schizodon nasutus, and Paravandellia oxyfera

The major contribution in weight was given by Hoplias malabaricus, followed by Salminus hilarii, and Hypostomus ancistroides. The largest specimen captured was a "tabarana" (Salminus hilarii), with $532 \mathrm{~g}$, and the smallest was a fish ectoparasite (Paravandellia oxyfera), with less than $0.01 \mathrm{~g}$, found attached to the body of a Steindachnerina insculpta.

The Shannon index showed significant differences among the sampled sites, considering as a number ( $p=0.037$, Table 3 ) or weight of individuals ( $p=0.014$, Table 4). However, the behavior of diversity indices was not consistent depending on the data type used (Table 2). Diversity in number at the confluence showed low values, differing only from the mid part. However, using weight, the highest diversity was observed in the headwaters, tending to diminish towards the confluence, however, differing significantly only from the confluence (Table 5).

The Shannon equitability was very similar among the sampled points (Table 7). The data for the number of individuals showed a homogeneous variance (Bartlett test: $\left.\mathrm{X}^{2}=4.57<\mathrm{X}_{0.05 ; 2}^{2}=5.99\right)$ and the ANOVA among points did not show significant differences $(\mathrm{p}=0.116)$. Considering equitability in weight (Table 6), dispersion of data in the headwater portion was lower compared to other points (Bartlett test: $\mathrm{X}^{2}=6.63>\mathrm{X}^{2}{ }_{0.05 ; 2}=5.99$ ). However, the Kruskal-Wallis test did not reveal significant differences $\left(\mathrm{X}^{2}=0.477 ; \mathrm{p}=0.788\right)$. Jackknife estimates, applied to the indices of diversity and ShannonWiener equitability, showed a great overlap among the confident intervals of the sampled points. The expected theoretical behavior having an increase of indices along the river was not observed.

Concerning the number of species captured, differences among points were significant (Kruskal-Wallis: $\left.\mathrm{X}^{2}=7.016 ; \mathrm{p}=0.030\right)$. The a posteriori non parametric test (Zar, 1999) revealed that the differences occurred only between the headwater and the confluence (Table 8) and the loss of species richness in the confluence was evident. At this point, only six species were captured, with a predominance of Serrasalmus spilopleura (15 individuals) and Hoplias malabaricus (13 individuals), both accounting for $80 \%$ in number and $80.2 \%$ in weight. The remaining species showed the following abundance: Astyanax altiparanae with 4 individuals and Callichthys callichthys, Geophagus brasiliensis, and Hoplosternum littorale represented by only one specimen. The Morisita-Horn index did not detect the effect of the pollution on the abundance and species composition, but showed the longitudinal distance, where the most different portions were the headwater and the confluence and the most similar ones were the mid portion and the confluence (Table 9).

Data on the standard length of Hoplias malabaricus from the three sampled points are shown in Tables 10 and 11 . The lowest variability occurred in the confluence (Bartlett test: $X^{2}=15.65>X_{0.05 ; 2}^{2}=5.99$ ), which is under the effect of the drain discharge. Mean population size at this point diminished significantly compared to the mid part and is similar to the headwater and contrasts to the initial prediction where the confluence would present larger specimens (Kruskal-Wallis: $\mathrm{X}^{2}=7.016$; $\mathrm{p}=0.030)$. 
Table 1. Taxonomic list of the fish caught in the Ribeirão Claro.

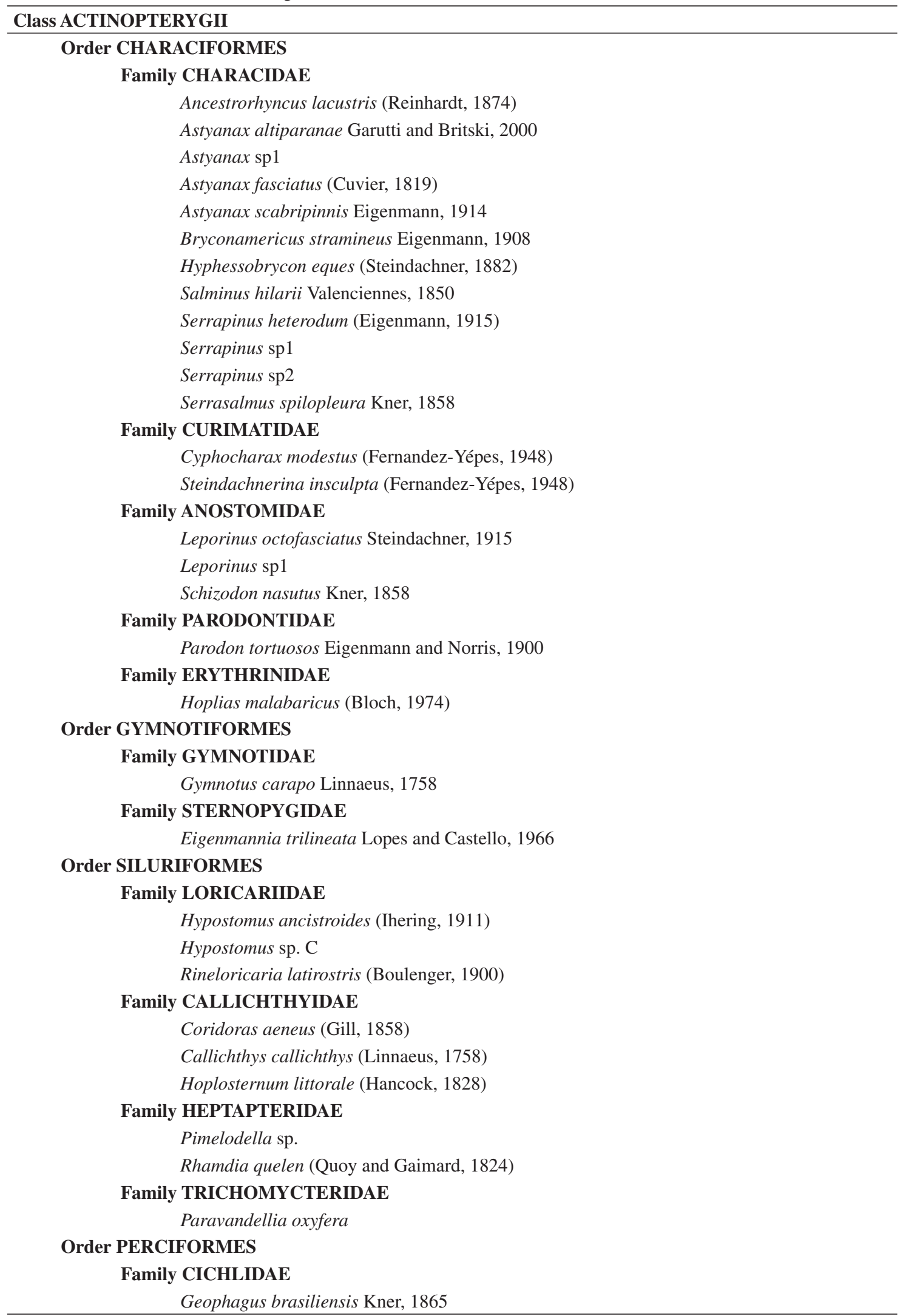


Table 2. Shannon-Wiener diversity indices.

\begin{tabular}{|c|c|c|c|c|c|c|}
\hline \multirow[t]{2}{*}{ Month } & \multicolumn{3}{|c|}{$\boldsymbol{H}_{N}{ }^{\prime}$} & \multicolumn{3}{|c|}{$\boldsymbol{H}_{W}{ }^{\prime}$} \\
\hline & Headwater & Mid & Confluence & Headwater & Mid & Confluence \\
\hline December - 2003 & 2.909 & 2.807 & - & 3.041 & 1.224 & - \\
\hline January - 2004 & 2.792 & 2.725 & 1.406 & 2.620 & 2.398 & 0.653 \\
\hline February - 2004 & 1.843 & 2.477 & 1.463 & 3.319 & 2.743 & 1.392 \\
\hline March - 2004 & 1.439 & 3.406 & 1.891 & 3.053 & 2.871 & 1.814 \\
\hline Mean & 2.246 & 2.854 & 1.586 & 3.008 & 2.309 & 1.287 \\
\hline Standard deviation & 0.719 & 0.394 & 0.265 & 0.289 & 0.750 & 0.588 \\
\hline Coeficcient of variation (\%) & 32.01 & 13.81 & 16.71 & 9.61 & 32.48 & 45.69 \\
\hline
\end{tabular}

$H^{\prime}{ }_{N}$ Shannon-Wiener index, calculated for number of individuals; and $H^{\prime}{ }_{W}$ Shannon-Wiener index, calculated for individual weight $(\mathrm{g})$.

Table 3. ANOVA for the Shannon-Wiener diversity index $\left(H_{N}\right.$, bit/individual).

\begin{tabular}{lccccc}
\hline $\begin{array}{l}\text { Source of } \\
\text { variation }\end{array}$ & SS & df & MS & F & P \\
\hline River part & 2.764 & 2 & 1.382 & 5.123 & 0.037 \\
Residual & 2.158 & 8 & 0.270 & - & - \\
\hline$H^{\prime}$ Shannon-Wiener index, calculated for number of indi- \\
viduals.
\end{tabular}

Table 4. ANOVA for the Shannon-Wiener diversity index $\left(H_{W}, \mathrm{~g}\right)$.

\begin{tabular}{lccccc}
\hline $\begin{array}{c}\text { Source of } \\
\text { variation }\end{array}$ & SS & df & MS & F & P \\
\hline River part & 5.086 & 2 & 2.543 & 7.732 & 0.014 \\
Residual & 2.631 & 8 & 0.329 & - & - \\
\hline
\end{tabular}

$\overline{H^{\prime}{ }_{W} \text { - Shannon-Wiener index, calculated for individual }}$ weight $(\mathrm{g})$.

Table 5. A posteriori Scheffé test for the Shannon-Wiener diversity indices.

\begin{tabular}{lcc}
\hline & $\boldsymbol{H}^{\prime}{ }_{N}$ & $\boldsymbol{H}^{\prime}{ }_{W}$ \\
\hline $\begin{array}{l}\text { Headwater x Mid } \\
\text { course }\end{array}$ & $0.608(0.308)$ & $-0.700(0.282)$ \\
$\begin{array}{l}\text { Headwater X } \\
\text { Confluence }\end{array}$ & $-0.659(0.306)$ & $-1.722(0.014)$ \\
$\begin{array}{l}\text { Mid course x } \\
\text { Confluence }\end{array}$ & $-1.267(0.037)$ & $-1.022(0.125)$ \\
\hline
\end{tabular}

$H^{\prime}{ }_{N}$ - Shannon-Wiener index, calculated for number of individuals; and $H^{\prime}{ }_{W}$ - Shannon-Wiener index, calculated for individual weight $(\mathrm{g})$, probability given by the a posteriori Scheffé test (in parenthesis).

\section{Discussion}

\subsection{Community structure}

The South American continent has the largest number of freshwater fish species than any other zoogeographic region including Central America. Approximately
8,000 species are estimated, which represents $24 \%$ of the fish species known in the world (Vari and Malabarba, 1998). Such ichthyofauna is mostly represented by the orders of Characiformes and Siluriformes. The order Characiformes is predominantly composed by fish in the Characidae family and considered the morphologically and taxonomically most diverse vertebrate group (LoweMcConnell, 1975).

Although the number of studies in ichthyology has been increasing in this region, the taxonomic composition, structure and general biology of Neotropical fish are poorly known (Vari and Malabarba, 1998). This is especially true for the large number of small streams, where about $50 \%$ of the species have small sizes and a high degree of endemism occurs (Castro, 1999).

The taxonomic composition of the Ribeirão Claro River did not differ from that cited above, and as in other South American streams, most of the species (80\%) had a length which was less than $15 \mathrm{~cm}$, with a great contribution of certain species, such as Hypostomus ancistroides, which is considered an exclusive inhabitant of streams in the Alto Paraná Basin (Castro and Casatti, 1997 apud Castro, 1999).

In tropical streams, communities are affected by seasonal events of flood and drought, which interfere in the size, composition, diversity and habitat availability. Additionally, such events affect the abundance and age distribution of the resident populations as well as immigrant species that come (Lowe-McConnell, 1975).

Contrasting to studies done by Pedro Neto (1996) and Cetra (2003), which emphasized the temporal effect on the community in the Corumbataí and Ribeirão Claro river basins, the present study may be considered as a picture of the peak flooding season and its consequences on the community with few habitats being repeatedly sampled over a short period of time. This period is considered the climax of the reproductive period for the majority of the tropical species (Lowe-McConnell, 1975).

Our results showed the presence of species rarely sampled in this region, although they are known to be present in rivers and streams of the Paraná River Basin, such as Callichthys callichthys, Eigenmannia trilineata, and Paravandellia oxyfera. This fact reinforces the need 
Table 6. Equitability of Shannon-Wiener.

\begin{tabular}{|c|c|c|c|c|c|c|}
\hline \multirow[t]{2}{*}{ Month } & \multicolumn{3}{|c|}{$E_{N}\left(\mathrm{n}^{0}\right.$ individuals $)$} & \multicolumn{3}{|c|}{$E_{W}$ (weight, gs) } \\
\hline & Headwater & Mid course & Confluence & Headwater & Mid course & Confluence \\
\hline December - 2003 & 1.213 & 1.219 & - & 1.268 & 0.531 & - \\
\hline January - 2004 & 1.213 & 1.401 & 1.279 & 1.138 & 1.232 & 0.595 \\
\hline February - 2004 & 0.650 & 1.273 & 1.055 & 1.171 & 1.410 & 1.004 \\
\hline March - 2004 & 0.561 & 1.228 & 1.364 & 1.190 & 1.035 & 1.309 \\
\hline Mean & 0.909 & 1.280 & 1.233 & 1.192 & 1.052 & 0.969 \\
\hline Standard deviation & 0.352 & 0.084 & 0.160 & 0.055 & 0.379 & 0.358 \\
\hline $\begin{array}{l}\text { Coeficcient of variation } \\
(\%)\end{array}$ & 38.72 & 6.56 & 12.98 & 4.61 & 36.03 & 36.95 \\
\hline
\end{tabular}

$E_{N}$ equitability of the Shannon-Wiener index, calculated for number of individuals; and $E_{W}$ equitability of the ShannonWiener index, calculated for individual weight $(\mathrm{g})$.

Table 7. Jackknife estimates and the confidence intervals (in parenthesis) for the indices of diversity H' and equitability E of Shannon-Wiener.

\begin{tabular}{clll}
\hline & \multicolumn{1}{c}{ Headwater } & \multicolumn{1}{c}{ Mid course } & \multicolumn{1}{c}{ Confluence } \\
\hline$H^{\prime}{ }_{N}$ & 2.323 & 4.304 & 3.888 \\
& $(1.034-3.612)$ & $(3.729-4.878)$ & $(2.999-4.776)$ \\
$H^{\prime}{ }_{W}$ & 3.800 & 3.791 & 3.309 \\
& $(3.304-4.296)$ & $(2.515-5.067)$ & $(1.969-4.650)$ \\
$\mathrm{E}_{\mathrm{N}}$ & 0.627 & 1.222 & 1.910 \\
& $(0.119-1.135)$ & $(1.112-1.331)$ & $(1.136-2.684)$ \\
$\mathrm{E}_{\mathrm{W}}$ & 1.047 & 1.084 & 1.644 \\
& $(0.947-1.146)$ & $(0.736-1.432)$ & $(1.032-2.257)$ \\
\hline
\end{tabular}

$H^{\prime}{ }_{N}$ - Shannon-Wiener index, calculated for number of individuals; $H^{\prime}{ }_{W}$ - Shannon-Wiener index, calculated for individual weight $(\mathrm{g}) ; \mathrm{E}_{\mathrm{N}}-$ Equitability of the Shannon-Wiener, calculated for number of individuals; and $\mathrm{E}_{\mathrm{w}}$ Equitability of the Shannon-Wiener, calculated for individual weight $(\mathrm{g})$.

Table 8. A posteriori non parametric test for comparison of means.

\begin{tabular}{lll}
\hline & $\mathrm{Q}_{\text {calc }}$ & $\mathrm{Q}_{\mathbf{0 . 0 5} 3}$ \\
\hline Headwater x Mid course & 0.966 & 2.394 \\
Headwater x Confluence & 2.633 & \\
Mid course x Confluence & 1.739 \\
\hline $\mathrm{Q}_{\text {calc }}$ calculated Q; and $\mathrm{Q}_{0.05 ; 3}$ expected value $5 \%$ and \\
3 groups.
\end{tabular}

Table 9. Morisita-Horn similarity matrix for number of individuals.

\begin{tabular}{lccc}
\hline & Headwater & Mid course & Confluence \\
\hline Headwater & 1 & - & - \\
Mid course & 0.1641 & 1 & - \\
Confluence & 0.0633 & 0.3173 & 1 \\
\hline
\end{tabular}

for improvement of sample techniques in order to better characterize these communities.

The good preservation status of the surrounding environment of the Ribeirão Claro upstream from the area of water impounding revealed a fish assemblage with low dominance and a well established trophic structure, mainly in the upper parts of the river (Cetra, 2003). In the previous mentioned study, the estimated species richness for the Corumbataí River Basin was of 43 species, with a maximum of 55, and a Shannon index (number of individuals) for the Ribeirão Claro was estimated at 4.22 bits/individual.

The number and species composition observed in the present study, along with the indices of diversity and equitability, corroborate with previous studies, revealing a well structured community in the Ribeirão Claro with a low dominance and important species richness in the basin, especially at points 1 and 2 . This pattern may be related to the good preservation status of the marginal vegetation from the mid portion in the Floresta Estadual "Edmundo Navarro de Andrade" up to the Floresta São José, close to its headwaters (Cetra, 2003). This provides an ample array of relatively well preserved habitats along almost the whole river, which in turn provides the matter required by the biota for its development, which in small streams comes essentially from allochthonous sources.

The River Continuum Concept (RCC) of Vannote et al., (1980) predicts an increase in species diversity along the river. Other studies confirmed the increase of richness and diversity in the headwater-confluence direction associated to an increase in area, volume, and posi- 
Table 10. Standard length of Hoplias malabaricus, $\mathrm{n}=36$.

\begin{tabular}{lccc}
\hline & Headwater & Mid course & Confluence \\
\hline Minimum & 36 & 104 & 102 \\
Maximum & 198 & 223.0 & 143 \\
Median & 136.0 & 161.5 & 123.0 \\
Standart deviation & 47.2 & 36.4 & 12.6 \\
\hline Bartlett test & \multicolumn{4}{c}{$\mathrm{X}^{2}=15.65>\mathrm{X}_{0,05 ; 2}^{2}=5.99$} \\
\hline Kruskal-Wallis test & $\mathrm{X}^{2}=7.016 ; \mathrm{p}=0.030$ \\
\hline
\end{tabular}

Table 11. Non-parametric test a posteriori comparing group means.

\begin{tabular}{lcc}
\hline & $\mathbf{Q}_{\text {calc }}$ & $\mathbf{Q}_{\mathbf{0}, 05 ; 3}$ \\
\hline Headwater x Mid course & 1.468 & 2.394 \\
Headwater x Confluence & 1.089 & - \\
Mid course x Confluence & 2.645 & - \\
\hline $\mathrm{Q}_{\text {calc }}$ calculated Q; and $\mathrm{Q}_{0.05 ; 3}$ expected value & $5 \%$ and \\
3 groups.
\end{tabular}

tion of the drainage system (Angermeier and Schlosser, 1989; Barrella and Petrere, 1994; Osborne and Wiley, 1991). As observed by Cetra (op. cit.), the fish community of the Ribeirão Claro does not fit the model, because it has an impact below by sewage and its original vegetation was replaced by Eucaliptus spp. and pasture, leading to a decrease in fish diversity, contrary to the expected by the RCC.

Another question is related to the type of data used for diversity measures. In the lake Baía da Onça, in the Pantanal, Catella (1992) observed that the species distribution was more homogeneous in weight than in the number of individuals. In the headwater of the Ribeirão Claro, the high capture of Serrapinus heterodum and Astyanax altiparanae was responsible for the increase in dominance; these species accounted for $72.1 \%$ of the number of individuals, however they contributed for only $16 \%$ in weight.

Amaral and Petrere (2001) discuss that in ecology the unit of measure (abundance in number or weight of individuals) deals with the environment complexity and may lead to different conclusions. Therefore, the choice of number or weight depends on the aim of the community study. Thus, we may argue that in relation to resource allocation, the amount of matter and energy that one species uses is due to its total biomass and, thus, the estimation of diversity in weight may better describe its niche use Catella (op. cit.).

It was not possible to detect changes in the community along the river using the Shannon equitability, which only showed that the headwater was less variable throughout the study. With regards to this similarity, it is important to note that the Ribeirão Claro is a stream only $43 \mathrm{~km}$ long from the headwaters up to the confluence with the Corumbataí River, and that the distance between the headwater and the mid part is less than
$20 \mathrm{~km}$. The region of the headwater is unique of the order 3 , however, approximately $500 \mathrm{~m}$ downstream, there is an encounter with another tributary that forms its springs (Figure 1), increasing the water volume and increasing the classification to the order of 4 . These factors associated to fish mobility may mask alterations in richness and dominance from one part to another, even if they are present.

\subsection{Pollution effects on the community}

Freshwater habitats have been much more modified and polluted than any other ecosystem in the biosphere. Sewage discharge is in conflict with water usage for humans and animal consumption, water abstraction, etc. (Maitland and Morgan, 1997; Sand-Jensen, 2001).

Metcalfe-Smith (1996) points out that evaluations of environmental quality measured in biological communities are more advantageous than chemical analyses of water because they accumulate pollutants. Harris (1995) apud Cetra (2003) states that fish give an integrated overview of the aquatic environment by the availability of information, ample variety of feeding habits and by presenting representatives at the top of the trophic web. According to Esteves and Aranha (1999), fish play an important role in the trophic web by controlling the abundance of many other organisms and anthropic alterations that affect their populations which may disturb the transfer of matter and energy through the ecosystem.

Coradi (1993) detected statistically significant alterations in benthic macroinvertebrate communities in Ribeirão Claro, distinguishing impacted areas due to sewage. In the present study, diversity indices did not reveal the expected pattern for the fish community under the influence of drain discharge: a decrease in species richness and dominance increase. However, the fact that equitability did not differ significantly may have masked the effect of richness decrease. The similarity index of Morisita-Horn revealed no effects of environmental conditions in the end part of the Ribeirão Claro and only the longitudinal gradient is evident. In such a direction, the headwater and the confluence were the most different parts, probably due to the distance and degree of isolation between both parts, since the mid part was similar to the other two points.

In freshwater lotic systems, fish populations may show traits which include them into two extreme groups: (1) one group that can withstand great variations in tem- 
perature and dissolved oxygen concentration, able to survive under stress or in lentic habitats, such as marginal ponds subject to desiccation, and (2) another group that, due to alterations, searches for cold and more oxygenated waters (Welcomme, 1994). An example of the first group is given by Hoplias malabaricus, a species widely distributed throughout South America. The second group may be represented by large migratory species, such as Salminus maxillosus, which are the first to disappear subsequent to anthropic alterations, such as dammimg or river pollution, when they are precluded from reaching more favorable habitats (Suzuki et al., 1997). Vono (2002) apud Sanches (2002) mentioned the subsequent increase in the density of piscivorous fish following the damming of the Porto Primavera, Araguai River-MG. In the final part of the Ribeirão Claro, besides the excess of pollutants, there is an old dam, which is not active nowadays. The trophic structure of this community showed was completely altered and predominantly consists of two piscivorous species, the "piranha" (Serrasalmus spilopleura) and the "traíra" (Hoplias malabaricus). Still concerning individuals of "traíra", we can not infer any physiological factors leading to their reduction in body size at this point of the river and studies on this specific subject are needed to clarify the issue. However, considering the period when the study was conducted, one scenario is possible: larger specimens with higher fecundity may have to migrate to more suitable areas. In this case, the colonization of the confluence of the Ribeirão Claro would depend on the migratory events. However, as the "traíra" is not considered a migratory species, an inadequate area for reproduction could prevent the local establishment of the species.

Decrease in species richness was noticeable. At this sampled point, the excess of organic material caused dissolved oxygen depletion, and the presence of some species with special traits to withstand stressed habitats was common, such as Hoplosternum littorale and Callichthys callichthys, known by presenting accessory respiration. Hoplosternum littorale was captured in great abundance at this same point by Cetra (2003) and at another polluted part of the Ribeirão Claro by Pedro Neto (1996). Callichthys callichthys was also associated to polluted and lentic waters in the Tietê River (Barrella and Petrere, 2003).

Acknowledgments - To FAPESP (Processo IC nº. 03/11530-9), UNESP and CNPq for the facilities and partial financial support.

\section{References}

AMARAL, BD. and PETRERE Jr., M., 2001. The $\alpha$ and $\beta$ diversities in the fish assemblages of the Promissão reservoir (SP-Brazil): scales, complexities and ecotone heterogeneity. Ecohydrology \& Hydrobiology, vol. 1, no. 1, p. 185-193.

ANGERMEIER, PL. and SCHLOSSER, IJ., 1989. Speciesarea relationships for stream fishes. Ecology, vol. 70, no. 5 , p. $1450-1462$.
BARRELLA, W. and PETRERE Jr., M., 1994. The influence of environmental factors on fish community structure in the Jacaré Pepira River, Brazil, pp.161-170. In: I. G. COWX (ed.), Rehabilitation of freshwater fisheries. Fishing News Book, London, 486p.

BARRELLA, W. and PETRERE Jr., M., 2003. Fish community alterations due to pollution and damming in Tietê and Paranapanema Rivers (Brazil). River Research and Applications, vol. 19, p. 59-76.

BARRElla, W., PETRERE Jr., M., SMITH, WS. and MONTAG, LFA., 2000. As Relações entre as matas ciliares, os rios e os peixes, p.187-207. In: R. R. RODRIGUES and H. F. LEITÃO-FILHO (eds.). Matas ciliares: conservação $e$ recuperação. Edusp, São Paulo, 320p.

BEGON, M., HARPER, JL. and TOWNSEND, CR., 1996. Ecology: individuals, populations and community. 2nd. ed., Blackwell Science, London, 1068p.

BRITTSKI, HA., SATO, Y. and ROSA, ABS., 1984. Manual de identificação de peixes da região de Três Marias: com chaves de identificação para os peixes da Bacia do São Francisco. Câmara dos Deputados, Coordenação de Publicações, Brasília, 143p.

BRITTSKI, HA., SILIMON, KS. and LOPES, BS., 1999. Peixes do Pantanal: manual de identificação. Embrapa-SPI, Brasília, 184p.

CASTRO, RMC., 1999. Evolução da ictiofauna de riachos Sul-americanos: padrões gerais e possíveis processos causais. In: E. P. CARAMASCHI, R. MAZZONI and P. R. PERESNETO (eds), Ecologia de Peixes de Riachos. Série Oecologia Brasiliensis, Rio de Janeiro, vol. 6, p. 139-155.

CATELLA, AC., 1992. Estrutura da comunidade e alimentação dos peixes da Baía da Onça, uma lagoa do Pantanal do Rio Aquidauana, MS. Dissertação de Mestrado, UNICAMP, Campinas, 215p.

CETESB., 1984. Qualidade das águas interiores do Estado de São Paulo. CETESB, São Paulo, 134p.

CETRA, M., 2003. Caracterização das assembléias de peixes da bacia do rio Corumbataí. Dissertação de Doutorado, Universidade de São Paulo, São Carlos, 88p.

CHAPMAN, JL. and REISS, MJ., 1997. Ecology: principles and applications. 5nd. ed., Cambridge University Press, New York, 294p.

CORADI, NM., 1993. Modificações na estrutura de comunidades de macroinvertebrados bentônicos do Ribeirão Claro (Rio Claro - SP) provocadas pela descarga de esgoto doméstico. Trabalho de Formatura, Universidade Estadual Paulista, Rio Claro, SP, 77p.

ESTEVES, KE. and ARANHA, JMR., 1999. Ecologia trófica de peixes de riachos. In: E. P. CARAMASCHI, R. MAZZONI and P. R. PERES-NETO (eds), Ecologia de Peixes de Riachos. Série Oecologia Brasiliensis, Rio de Janeiro, vol. 6, p. $157-182$.

GARCIA, GJ., HEBERT, HD., PERINOTTO, JAJ. and CASTRO, JFM., 2004. (eds) Atlas ambiental da bacia do rio Corumbataí, 13 de março 2004. World Wide Web site: www. rc.unesp.br.

GERTEL, P., 2002. Estudo dos impactos ambientais negativos do córrego São Joaquim na bacia do Ribeirão Claro. Trabalho de Formatura, Universidade Estadual Paulista, Rio Claro, 62p. 
KREBS, CJ., 1999. Ecological methodology. 2nd. ed., Harper \& Row, New York, 620p.

LOWE-McCONNELL, RH., 1975. Fish communities in tropical freshwaters: their distribution, ecology and evolution. Longman, London, 337p.

LOWE-McCONNELL, RH., 1999. Estudos ecológicos de comunidades de peixes tropicais. Edusp, São Paulo, 534p.

MAGURRAN, AE., 1988. Ecological diversity and its measurement. Chapman and Hall, New York, 179p.

MAITLAND, PS. and MORGAN, NC., 1997. Conservation management of freshwater habitats: lakes, rivers and wetlands. Chapman and Hall, New York, 233p.

METCALFE-SMITH, JL., 1996. Biological water-quality assessment of rivers: use of macroinvertabrate communities, $p$. 17-43. In: GE. PETTS and P. CALOW (eds.), River restoration. Blackwell Science, London, 231p.

OSBORNE, LL. and WILEY, MJ., 1991. Influence of tributary spatial position on the structure of warmwater fish communities. Canadian Journal of Fisheries and Aquatic Sciences, vol. 49, p. 671-681.

PALMA-SILVA, GM., 1999. Diagnóstico ambiental, qualidade de água e índice de depuração do rio Corumbataí-SP. Dissertação de Mestrado, Universidade Estadual Paulista, Rio Claro, 155p.

PEDRO NETO, MP., 1996. Efeito da descarga de esgoto sobre a estrutura da comunidade de peixes do Ribeirão Claro. Trabalho de Formatura, Universidade Estadual Paulista, Rio Claro, 37p.

PERES-NETO, PR., 1995. Estrutura de comunidades de peixes ao longo de um gradiente lótico de um rio costeiro do leste brasileiro (rio Macacu, R.J.). Dissertação de Mestrado, Universidade Federal do Rio de Janeiro, Rio de Janeiro, 87p.

PETTS, G. and CALOW, P., 1996. The nature of rivers, pp.16. In: GE. PETTS and PCALOW (eds.), River restoration. Blackwell Science, London, 231p.

PREFEITURA DE RIO CLARO., 1992. Plano diretor de desenvolvimento de Rio Claro. Rio Claro-SP, 64p.
RICKLEFS, RE., 1993. A economia da natureza. 3nd. ed., Trad. C. Bueno and PPL. Silva, Guanabara Koogan, Rio de Janeiro, 470p.

SANCHES, PV., 2002. Influências do fluxo, nível e canais sobre a deriva e alterações causadas pelo barramento sobre o ictioplâncton na região do alto rio Paraná, Brasil. Dissertação de Doutorado, Universidade Estadual de Maringá, Maringá, 2002, 47p.

SAND-JENSEN, K., 2001. Freshwater ecosystems, humam impact on. Encyclopedia of Biodiversity, vol. 3, p. 89-108.

SPICACCI, MTB., 1990. Avaliação da qualidade de água após o lançamento de esgotos no Ribeirão Claro (Rio Claro-SP). Trabalho de Formatura, Universidade Estadual Paulista, Rio Claro, 87p.

STILING, PD., 1996. Ecology: theories and applications. 2nd. ed., Prentice Hall, New Jersey, 539p.

SÚAREZ, YR. and PETRERE Jr., M., 2003. Associações de espécies de peixes em ambientes lóticos da bacia do rio Iguatemi, Estado do Mato Grosso do Sul. Acta Scientiarum. Biological Sciences, vol. 25, no. 2, p. 361-367.

SUSUKI, HI., PAVANELLI, CS., FUJI, R., BINI, LM. and AGOSTINHO, AA., 1997. Ictiofauna de quatro tributários do reservatório de Segredo, p. 259-273. In: AGOSTINHO, AA. and GOMES, LC. (eds.), Reservatório de Segredo: bases ecológicas para o manejo. EDUEM, Maringá, 364p.

VANNOTE, RL., MINSHALL, GW., CUMMINS, KW., SEDELL, JR. and CUSHING, CE., 1980. The river continuum concept. Canadian Journal of Fisheries and Aquatic Sciences, vol. 37, p. 130-137.

VARI, RP. and MALABARBA, LR., 1998. Neotropical ichthyology: an overview, p. 1-11. In: LR. MALABARBA, RE. REIS, RP. VARI, ZMS. LUCENA and CAS. LUCENA (eds.), Phylogeny and classification of neotropical fishes. EDIPUCRS, Porto Alegre 603p.

WELCOMME, RL., 1994. The status of large river habitats, p. 11-20. In: I. G. COWX (ed.), Rehabilitation of freshwater fisheries. Fishing News Book, London, 486p.

ZAR, JH., 1999. Biostatistical analysis. 4nd. ed., Prentice-Hall, New Jersey, 786p. 